TARNOWSKIE STUDIA TEOLOGICZNE 37 (2018) NR 1-2, S. 263-279 http://dx.doi.org/10.15633/tst.3262

ks. Ireneusz Stolarczyk ${ }^{1}$

UNIWERSYTET PAPIESKI JANA PAWŁA II W KRAKOWIE

\title{
Nadprzyrodzony wymiar godności człowieka
}

Ideą przewodnią w całej nauce społecznej Kościoła jest wciąż powracająca prawda o godności osoby ludzkiej. Warto przeanalizować to zagadnienie, gdyż nieodłącznie towarzyszy ono społecznemu nauczaniu Kościoła.

Godność człowieka powinno się ujmować integralnie. Nie chodzi tylko o to, by uwzględniać poszczególne jego wymiary, ale także o to, by mieć świadomość, że tworzą one pewną całość i w tym sensie są właśnie integralne. Na godność człowieka, osoby ludzkiej, wskazuje wiele elementów, które jakkolwiek nakładają się wzajemnie na siebie, to jednak dadzą się jakoś wyodrębnić.

Niniejsza część opracowania ukazuje nadprzyrodzony wymiar godności człowieka. O godności tej świadczy Objawienie, zwłaszcza Pismo Święte wskazujące na fakt stworzenia człowieka przez Boga. Człowiek w tym ujęciu jest obrazem Boga.

Z uwagi na nadprzyrodzony aspekt ludzkiej godności możemy mówić o tym, że człowiek został wyniesiony do godności synostwa Bożego, stał się bratem Chrystusa. To właśnie człowiek jest celem Bożego objawienia, do człowieka przemawiał Chrystus, dla niego cierpiał, został skazany na śmierć i zmartwychwstał. Aspekt nadprzyrodzony ludzkiej godności wyraża się również w misji Kościoła Chrystusowego, dla którego właśnie człowiek jest ,jedyną drogą”.

1 Ks. dr hab. Ireneusz Stolarczyk, prof. UPJPII - ukończył studia w zakresie socjologii i nauki społecznej Kościoła na Katolickim Uniwersytecie Lubelskim, stypendysta Uniwersytetu Katolickiego w Bonn, prowadzi wykłady na Uniwersytecie Papieskim Jana Pawła II w Krakowie Wydział Teologiczny Sekcja w Tarnowie z katolickiej nauki społecznej oraz etyki społecznej i gospodarczej. Pełnił funkcję dziekana Wydziału Teologicznego Sekcja w Tarnowie Uniwersytetu Papieskiego Jana Pawła II w Krakowie. Autor publikacji z zakresu myśli społecznej Kościoła, ze szczególnym uwzględnieniem wartościowania globalizacji i wpływu tego procesu na dotychczasowe struktury życia społecznego, kultury i polityki. W publikacjach podejmuje również tematykę związaną z interpretacją zasad etyczno-społecznych wypracowanych w nauczaniu społecznym Kościoła. 


\section{Biblijna koncepcja godności człowieka}

Godność człowieka wiąże się nierozerwalnie z religijnym wymiarem jego działania. Jeśli bowiem życie ludzkie i sens podejmowanych przez niego najbardziej ludzkich działań nie tłumaczy się ostatecznie prawami przyrody, jako zespołem relacji przyczynowych, lecz przeciwnie, tłumaczy się przez relacje międzyosobowe, nacechowane „racją bytu sensowności” tychże działań ludzkich, to oznacza to, iż każda osoba jest zanurzona nieustannie w „klimacie religijnym”, czyli takim, w którym uzasadniamy sensowność naszego działania ludzkiego przez odwołanie się i przyporządkowanie życia drugiej osobie, drugiemu „ty” - ostatecznie zaś „Ty” Absolutu. Zatem druga osoba może nadać sens życiu i działalności człowieka, istnieje jednak ryzyko, że taka osoba może być traktowana jako bóg lub bóstwo ${ }^{2}$.

Gdy sięgniemy myślą wstecz do literatury starogreckiej, możemy zauważyć intrygujący sposób reagowania Greków na wspomnianą wyżej zasadę tworzenia bóstw lub bogów przez człowieka. Przyroda stawiająca przeszkodę działaniu ludzkiemu lub jego zamierzeniu (czy pomagająca spełniać ludzkie zamierzenia) zostawała natychmiast upersonifikowana, stawała się odpowiednim bóstwem. Bóstwami stały się zatem źródła, rzeki, ocean, powietrze itd. Grecy bowiem instynktownie wyczuwali, że uzasadnienia dla ludzkiego życia świadomego nie można szukać w sferze niższej od człowieka, a uzasadnienia dla bytu nie można szukać w niebycie. $Z$ tego powodu kontekst ludzkiego życia zostawał przenoszony w sferę bogów - jedynie oni mogli jakoś uzasadnić ludzkie działanie i postępowanie. Owo odniesienie się do innej osoby, jako uzasadniającej zwłaszcza celowość (ale nie tylko) ludzkiego postępowania, wprowadza nas w dziedzinę religii, która syntetyzuje wszystkie akty życia osobowego, zwłaszcza w dziedzinę religii mającej za przedmiot odniesienia Boga osobowego, który jest Absolutem, a więc bytem w sobie, a przez to Dobrem, Prawdą, Pięknem ${ }^{3}$.

Źródłem zawierającym dane na temat godności człowieka jest niewątpliwie Księga Rodzaju. I chociaż nie można w niej znaleźć samego terminu „godność", to jednak zawiera ona ideę tego pojęcia, ponieważ mówi o stworzeniu człowieka na obraz i podobieństwo Boga, dzięki czemu człowiek uzyskał

\footnotetext{
2 Por. A. I. Heschel, Człowiek nie jest sam, Kraków 2001, s. 204-213.

3 Por. M. A. Krąpiec, Człowiek, w: Powszechna encyklopedia filozofii, red. A. Maryniarczyk, M. J. Gondek, t. 2, Lublin 2001, s. 376-386.
} 
wyjątkową pozycję w świecie (por. Rdz 1, 26). Teksty biblijne zawierają również szereg innych wypowiedzi wskazujących na wysoki status człowieka ${ }^{4}$. Człowiek jako mężczyzna i kobieta został stworzony na obraz Boży - Imago Dei (por. $\mathrm{Rdz} 1,27$ ). Całe stworzenie osiąga swój punkt kulminacyjny w powołaniu do życia człowieka, który został obdarzony „chwałą i czcią” (Ps 4, 6).

Ta królewska godność przynależy człowiekowi jako człowiekowi i jest pierwotna w stosunku do wszelkich różnic dotyczących płci, narodowości, religii lub klasy. Jest ona dziełem Boga i On sam jest jej gwarantem. Opis stworzenia człowieka wskazuje na jego transcendencję nad przyrodą i na jego szczególną więź z Bogiem. Człowiek jest kimś wyjątkowym w całym dziele stworzenias.

W nowotestamentalnym kontekście dzieła odkupienia aspekt godności człowieka ulega zradykalizowaniu poprzez wezwanie do godności dziecięctwa Bożego w Chrystusie: „A zatem nie jesteś już niewolnikiem, lecz synem. Jeżeli zaś synem, to i dziedzicem $\mathrm{z}$ woli Bożej” (Ga 4, 7). „Stworzenie zostanie wyzwolone $\mathrm{z}$ niewoli zepsucia, by uczestniczyć $\mathrm{w}$ wolności i chwale dzieci Bożych” (Rz 8, 21). „Bo wy wszyscy, którzy zostaliście ochrzczeni w Chrystusie, przyoblekliście się w Chrystusa. Nie ma już Żyda ani poganina, nie ma już niewolnika, ani człowieka wolnego, nie ma już mężczyzny ani kobiety, wszyscy bowiem jesteście kimś jednym w Chrystusie Jezusie" (Ga 3, 27).

Szczytem ludzkiej godności według Objawienia jest to, że sam Bóg przyjął ludzką naturę. Szczególnie tę prawdę uwydatnił św. Jan w Prologu, pisząc: „Na początku było Słowo, Słowo było u Boga, Bogiem było Słowo [...]. Słowo stało się ciałem i mieszkało między nami [...]" (J 1, 1. 14). Opis ludzkiego życia Słowa wcielonego, Jego śmierć i zmartwychwstanie w ludzkim ciele - wszystko to stanowi najwyższe potwierdzenie godności ludzkiego bytu osobowego, ze względu na szczególną więź człowieka z Bogiem.

Biblijna godność człowieka wiąże się z zagadnieniem wolności. W wielkim wyjściu z Egiptu do Ziemi Obiecanej, przejściu przez Morze Czerwone Bóg jawi się jako Wyzwoliciel; prowadzi swój lud z egipskiej ziemi niewoli do wolności.

Ogłoszone przez Boga prawo dobitnie napomina, by nie działać na szkodę i nie wykorzystywać osób najsłabszych w społeczeństwie: niewolników, wdów, sierot oraz przybyszów, a nawet by miłować bliźniego jak siebie samego (por. Kpł 19, 18). Jest to przejaw uzyskania wolności. Podobnie idea roku jubileuszowego (por. Kpł 25, 8-55), która zapewne nigdy nie została zrealizowana,

4 Por. F. J. Mazurek, Godność osoby ludzkiej podstawa praw człowieka, Lublin 2001, s. 23.

5 Por. R. Otowicz, Etyka życia, Kraków 1998, s. 79-88. 
przypomina Boży dezyderat: wciąż na nowo miał być przywracany stan, który według Księgi Liczb (por. 26, 52-56) ustanowił sam Bóg przy podziale ziemi, podczas wejścia Izraela do Ziemi Obiecanej. Miano dzielić się ziemią, bo ona potwierdza wolność i daje środki do życia. Troska o wolność ludzką wyrażała się także w misji wielu proroków, którzy przypominali o sądzie Bożym, jako czasie nadejścia Królestwa Pokoju, w którym zapanuje sprawiedliwość i równość. Ponadto prorocy sami stawali w obronie praw uciśnionych i wzywali Naród Wybrany do pełnienia dzieł miłosierdzia.

W Nowym Testamencie godność człowieka dana mu przez Boga i uwarunkowana dziełem odkupienia („wolność i chwała dzieci Bożych”), odnoszona jest do wolności przede wszystkim w wymiarze duchowym i eschatologicznym, natomiast jest prawie całkowicie pozbawiona jakiegokolwiek prawno-etycznego odniesienia do spraw tego świata, co zapewne wynikało z - obecnej w Kościele pierwotnym - postawy oczekiwania na powtórne przyjście Chrystusa. O ile św. Paweł $\mathrm{z}$ naciskiem podkreślał, że w Chrystusie nie ma niewolników ani wolnych, o tyle nie leżało w jego intencji podawanie w wątpliwość niewolnictwa jako społecznej instytucji sprzeniewierzającej się wolności człowieka - i to nawet w obrębie gminy chrześcijańskiej. Wprost przeciwnie: wzywa on każdego, by „pozostał w takim stanie, w jakim został powołany. Albowiem ten, kto został powołany w Panu jako niewolnik, jest wyzwoleńcem Pana. Podobnie i ten, kto został powołany jako wolny, staje się niewolnikiem Chrystusa" (1 Kor 7, 20-22). Dlatego też odsyła zbiegłego chrześcijańskiego niewolnika Onezyma do jego Pana - Filemona nawróconego przez Pawła. Ten winien go przyjąć „jako brata umiłowanego" (Flm 8, 20). Niewolnictwo jest więc co prawda łagodzone wewnątrz gminy w duchu patriarchalnej miłości, niemniej jednak pozostaje potwierdzone w swoim istnieniu jako instytucja.

Przykład św. Pawła pokazuje, że droga od chrześcijańskiego pojęcia godności człowieka do polityczno-prawnej gwarancji umocowanej poprzez podstawowe prawa człowieka nie jest prosta ani łatwa. Proces ten mógłby się dokonać jedynie w ramach struktur społeczno-historycznych, istniejących w czasach antycznych, w średniowieczu i w czasach nowożytnych. Struktury zachowań międzyludzkich, jakie powstawały w społeczeństwach na skutek panującego systemu społeczno-politycznego, np. panujący przez stulecia system feudalny wraz ze ścisłym powiązaniem władzy świeckiej i duchowej, nie dopuszczały jednakże do powstania takiego systemu prawnego, który interpretowałby godność człowieka z punktu widzenia praw i wolności jednostki. Dopiero powstanie coraz potężniejszego i coraz bardziej wpływowego, wykształconego i majętnego 
mieszczaństwa utworzyło warunki umożliwiające ów „zwrot ku podmiotowi”, którego skutkiem podczas wybuchających pod sztandarem wolności nowożytnych rewolucji mieszczańskich było żądanie - a wreszcie wywalczenie prawnych gwarancji dla respektowania godności człowieka. Fakt, że zwrot ten miał miejsce tylko w Europie, a nie w żadnym innym kręgu kulturowym, może mieć istnieć istotny związek z biblijno-chrześcijańską tradycją pojęcia godności człowieka ${ }^{6}$.

Odwoływanie się do godności człowieka napotyka na zasadnicze trudności. Nieuchronnie nasuwa się pytanie o istotę i przeznaczenie człowieka, a zatem pytanie o charakterze światopoglądowym. Odpowiedź jest zawsze związana $\mathrm{z}$ naszym rozumieniem siebie jako człowieka oraz ze stanowiskiem, jakie zajmujemy wobec różnorakich wypowiedzi na temat ludzkiej godności. Proponowane przez modernizm rozumienie wolności, której pojęcie zostało klasycznie sformułowane przez Kanta, prowadziło do pluralizacji światopoglądowych przekonań odnośnie do istoty i przeznaczenia człowieka. Ludzie, korzystając z wolności, sami kreują obraz własnego człowieczeństwa, a co za tym idzie proponują różne modele zachowań ludzkich, czy też modele bycia człowiekiem.

Ten problem ze zdwojoną siłą ujawnia się w dyskusji o wolności człowieka i różnorodności świata ludzkiego i zwierzęcego, a zwłaszcza na polu zagadnień o genetyce człowieka. Im większy pluralizm światopoglądowy panuje w naszych wyobrażeniach na temat istoty i przeznaczenia człowieka, tym liczniejsze i coraz bardziej różnorodne stają się odpowiedzi na pytanie, co właściwie oznacza godność człowieka. O ile odwoływanie się do godności człowieka nadal jest częste, o tyle samo jej pojęcie rozmywa się w różnorodności częściowo kontrowersyjnych opinii.

Obecnie jesteśmy świadkami nowej próby argumentowania pojęcia godności człowieka. Wszystkie zabiegi balansują pomiędzy dwoma skrajnymi zjawiskami. Z jednej strony mnoży się niezliczone argumenty na rzecz ukazania pojęcia godności ludzkiej, z drugiej natomiast próbuje się podważyć i nadszarpnąć to, co przez wieki było uznawane za fundamentalne i zasadnicze w pojęciu godności osoby ludzkiej. Problem ten nie jest prosty do rozwiązania, bo pokazuje wieloaspektowość zagadnienia. Przede wszystkim spór dotyczy kwestii, czy człowiek posiada jakąś istotną właściwość, która odróżniałaby go od innych istot żywych i uzasadniałaby jego godność. Od czasów antycznych, kiedy

6 Por. J. Gnilka, Teologia Nowego Testamentu, Kraków 2002, s. 44-88. 
to definiowano człowieka jako zôon lógon echon, a więc istotę mówiącą lub też posiadającą ducha, przez długi czas panowało przekonanie, że cechą tą jest mowa i duchowy rozum kierujący odpowiedzialnym i wolnym działaniem ${ }^{7}$.

Kiedy w obecnych postmetafizycznych czasach twierdzi się, że duch nie posiada samodzielnego znaczenia, znika różnica pomiędzy człowiekiem a zwierzęciem. Widać to szczególnie we współczesnej filozofii naturalistycznej, gdzie ludzkie myślenie zredukowane jest do fizyczno- chemicznego determinizmu dających się neurologicznie wyjaśnić procesów zachodzących w mózgu. Mocno podkreśla to przedstawiciel utylitaryzmu preferencyjnego mieszkający w Australii Peter Singer. Odmawia godności człowieka embrionom, płodom, noworodkom, osobom ciężko upośledzonym psychicznie, cierpiącym na starczą demencję oraz osobom przebywającym w śpiączce. Stąd prezentuje konkretne stanowisko odnośnie do aborcji, eutanazji, klonowania itd. ${ }^{8}$. Pojęcie „świętość życia” uważa za pojęcie lokalne i niemogące dotyczyć ogółu ani w sensie moralnym, ani prawnym ${ }^{9}$.

Innym aspektem definiowania godności ludzkiej jest to, co wynika z globalizacji i podkreślania w niej tylko elementu ekonomicznego. Coraz częstsze zawężanie i sprowadzanie wolności do wolności rynkowej dotyczy w istotny sposób godności człowieka oraz prawno-etycznych przekonań, według których zadaniem porządku prawnego jest stać na straży godności człowieka czy to w wymiarze praw i wolności jednostki, praw obywatelskich, czy też praw społecznych. Ma rację Jürgen Habermas, który wobec ekonomicznej kolonizacji naszego życia wzywa do większej wrażliwości na „zawartą w prawnych strukturach i wymagającą odnowy społeczną solidarność"10. Jeśli nie uda się ograniczyć neoliberalnego, globalizującego się kapitalizmu poprzez bazujące na prawach człowieka reguły ustanawiane w wymiarze narodowym i międzynarodowym, godność człowieka zostanie zredukowana do kwestii ekonomicznej zasady wydajności. To jednakże byłby koniec tej idei.

Co do sposobu definiowania godności ludzkiej istnieją różne opinie. Pojawiają się zacietrzewienia, nieodpowiedzialne odpowiedzi. Podstawowa zasada konstytucyjna mówiąca o godności człowieka stanowi przeszkodę dla

7 Por. H. U. von Balthasar, Teodramatyka. Druga osoba dramatu, Kraków 2003, s. 34-47; R. Legutko, Podzwonne dla błazna, Kraków 2006, s. 27-43.

8 Por. P. Singer, Practical Ethics, Cambridge 1979, s. 42.

9 Por. P. Singer, Practical Ethics, s. 56.

${ }^{10} \mathrm{H}$. Jürgen, Faktizität und Geltung. Beiträge zur Diskurstheorie des Rechts und des demokratischen Rechtsstaats, Frankfurt 1992, s. 12. 
przyrodników i polityków, a teoretykom prawa sprawia coraz więcej trudności. Pojęcie godności człowieka nie jest jasne, klarowne ani jednoznaczne, a to utrudnia ustanawianie prawa.

Trudno podać tylko jedną definicję (jednoznaczny tekst) w tak pluralistycznym świecie. Dlatego powątpiewa się, czy to pojecie, tak mocno ugruntowane w historii, odzyska swój wcześniejszy walor.

Zmagania o godność człowieka rozgrywają się pomiędzy możnością dogłębnego poznania człowieka a jego zachowaniem. A więc między logosem a etosem. W prowadzonym obecnie sporze o człowieka należy wziąć pod uwage następujące stanowiska: logos (bez etosu) godności człowieka; etos (bez logosu) godności człowieka; logos i etos godności ludzkiej. Dwa pierwsze stanowiska prowadzą do zniszczenia związku logosu z etosem. Na poziomie metaetycznej refleksji stanowiska te odpowiadają kolejno: naturalizmowi (empiryzmowi); emotymizmowi (decyzjonizmowi), intuicjonizmowi. Stanowiska pierwsze i trzecie - stanowią kognitywizm, natomiast drugie - akognitywizm ${ }^{11}$.

Tezę o logosie (bez etosu) godności ludzkiej reprezentuje naturalizm, do którego zalicza się aksjologiczny relatywizm kulturowy, głoszony przede wszystkim przez amerykańskich antropologów kultury i psychologów (behawiorystów), a także przez ortodoksyjny marksizm. Godność poszczególnych osób jest więc cechą empiryczną. Cechę tę można zdobywać lub tracić, zależnie od (nie-) godnego, (anty-)produktywnego zachowania się. Godność człowieka jest cechą (jakością) osobistą (ale nie osobową) odniesioną społecznie. Redukuje się w ten sposób etykę do historii, psychologii, socjologii, bądź nawet do biologii moralności. A więc nie tylko marksizm, ale wszystkie neopozytywistyczne kierunki w etyce prezentują to stanowisko. Odzwierciedla się w nim współczesna filozofia (post-)nowożytna oraz wszystkie cechy kultury naukowo-technicznej. W tym kontekście godność ludzka może być rozumiana wyłącznie jako taki logos, który jest „naukową”, a nie „metafizyczną” prawdą o człowieku ${ }^{12}$.

To samo pokazuje debata, która miała miejsce w Niemczech w latach osiemdziesiątych $\mathrm{xx}$ wieku na temat ludzkiej genetyki, jak np. votum separatum Doerflera dołączone do sprawozdania tzw. komisji Bendy. Tym, którzy nie są przyrodnikami, a więc etykom, zarzuca się fałszywe oceny i negatywne stanowisko odnośnie do badań genetycznych z powodu braku wystarczających informacji empirycznych. Mówi się, że przecież etyka wraz z jej

${ }^{11}$ Por. H. Jürgen, Faktizität und Geltung, s. 51.

${ }^{12}$ Por. H. Jürgen, Faktizität und Geltung, s. 51. 
pojęciem godności ludzkiej nie ma żadnego naukowego charakteru; a jeśli już, to godność nie jest właściwie żadną wewnętrzną wartością, nie opiera się na wewnętrznych cechach „nosiciela tej godności”, lecz tylko na zewnętrznym, faktycznym uznaniu jej ze strony innych ludzi. W konsekwencji jest ona u różnych osób różna. Współczesne myślenie oddzieliło pojęcie godności od jego metafizycznych korzeni i wyrzekło się uzasadnień wynikających zarówno $\mathrm{z}$ prawa naturalnego, jak i teologii chrześcijańskiej. Ponadto z punktu widzenia ideologicznego i naukowego przestrzega się przed niebezpieczeństwem „metafizycznych obciążeń” i ideologizacji porządku prawnego. Stawia się zarzuty, że pojęcie godności człowieka staje się koniem trojańskim, za pomocą którego określone światopoglądy oraz przekonania filozoficzne i religijne miałyby być przemycane do obszaru badań, polityki i systemu prawnego ${ }^{13}$.

Probierzem genetyki ludzkiej jest nie tylko godność człowieka. W związku z rozwojem inżynierii genetycznej trzeba postawić pytanie o to, czy nie dochodzi w niej do zmiany ludzkiej natury i do okaleczenia ludzkiej godności. Pojawienie się nowego przedmiotu, jakim jest genetyka ludzka, pozwala nam sprawdzić, czy aparatura pojęciowa wystarcza do właściwej interpretacji jednej z podstawowych zasad konstytucyjnych, czy wystarcza, by dać odpowiedź na nieznane wcześniej pytania.

Można oddzielać logos od etosu, ale wówczas w takiej ocenie całkowicie zanika logos, a definicja zatrzymuje się wyłącznie na etosie. Tezę tę reprezentuje metaetyczny emotywizm. Godność ludzka nie jest dla niego żadną uprzednio daną obiektywna wartością, wymaganiem skierowanym do człowieka, kryterium tego, co moralnie prawdziwe bądź fałszywe, żadną rzeczywistością poznania, lecz tylko subiektywno-egzystencjalnym przejawem życia i sferą odczuć parateoretycznego rodzaju. Godność ta nie da się ani udowodnić ani odeprzeć. Można w nią wierzyć bądź zaprzeczyć jej istnieniu. Na jej korzyść nie da się również przytoczyć żadnych logicznych racji. Dlatego, po prostu, wypada się za nią opowiedzieć, nawet nie mając po temu podstaw, tzn. w sposób irracjonalny. Trzeba się zdecydować na to, by uznać w każdym człowieku jego wartość osobistą.

Godność człowieka rodzi się na drodze jego własnych, wolnych i suwerennych decyzji i jest przez niego pogłębiana dzięki świadomości obowiązku. Tego rodzaju godność ludzie przyznają sobie wzajemnie. Według tego stanowiska godność ludzka nie jest żadną empiryczną bądź bytową cechą człowieczeństwa.

${ }^{13}$ Por. H. Jürgen, Faktizität und Geltung, s. 52-53. 
Nie stanowi przedmiotu poznania, z którego mogłaby płynąć jakaś wiedza wnosząca nowe informacje. Określenie „godność ludzka” nie jest żadnym imieniem, nie ma żadnego oznacznika w samej rzeczy - w rzeczywistości osobowego bytu. Pojęcie godności ludzkiej jest więc pojęciem pozornym, które nie ma żadnej funkcji semantycznej, a wyłącznie pragmatyczną, które nie może być używane jako orzecznik w wypowiedziach normatywno-prawnych i etycznych, tak że w końcu nie są już one zdaniami w logicznym sensie. Wypowiedzi te wyrażają wyłącznie odczucia i usiłują wywołać akceptację emocjonalną po to, by wyrażone w nich przekonanie stało się również udziałem kogoś drugiego.

Dyskusja dotycząca genetyki ludzkiej i inżynierii genetycznej dostarcza wielu przykładów, które wyraźnie przedstawiają emocjonalne przeciwstawienie i rozdzielenie logosu od etosu. Uczestnicy bitburskich rozmów (1986 roku) na temat techniki genetycznej i prawa uznali sformułowanie artykułu pierwszego niemieckiej konstytucji za „twierdzę dla teologów i moralistów” (Isensee), względnie za jej „hamulce bezpieczeństwa” (Vitzthum). Dla innych sformułowanie to było „logiczną, pustą formułą” (Topitsch), „pojęciem życzeniowym” (Luhman), które oznacza udaną „,samoprezentację, czystą manifestację dobrej woli”, koniecznym postulatem, „wędrującą wydmą”, która zależnie od okoliczności zmienia miejsce, tak że ludzki embrion mógł zostać nazwany „tworem podobnym do truskawki, wybujałą substancją pierwszej godziny” (Zeidler) ${ }^{14}$.

Godność ludzka jest rzeczywistością, którą najlepiej można poznać przez zrozumienie różnicy między człowiekiem a innymi istotami żywymi. Świat zwierząt potrafi zatroszczyć się o swoje życie, przystosować się do środowiska. Co więcej, zwierzęta mają relacje pomiędzy sobą i własne życie psychiczne. Brakuje im jednak tych przymiotów, które pozwoliłyby przypisać im status osoby i moralnego podmiotu właściwego człowiekowi ${ }^{15}$.

Człowiek przerasta świat zwierząt, ma wyjątkowe uzdolnienia: racjonalność i zdolność wyboru, ma zdolność metodycznego poznania i odczuwania obowiązków moralnych, jest jedynym podmiotem twórczości, za którą jest zdolny ponosić odpowiedzialność ${ }^{16}$. Nawet choroba, która uniemożliwia ujawnienie się tych cech, nie pozbawia ich. Człowiek jest nosicielem rozumnej natury ${ }^{17}$.

${ }^{14}$ H. Jürgen, Faktizität und Geltung, s. 54-56.

${ }_{15}$ Por. M. Głódź, Zagadka substancji wszechrzeczy i człowieka, w: M. Heller, J. Życiński, Wszechświat - maszyna czy myśl?, Kraków 1998, s. 127-142.

${ }_{16}$ Por. A. Gesché, Człowiek, Poznań 2005, s. 15-32.

${ }_{17}$ Por. M. A. Krąpiec, Kryzys społeczno-gospodarczy kryzysem człowieka, w: O życie godne człowieka, red. B. Bejze (W Nurcie Zagadnień Posoborowych 19), Warszawa 1990, s. 251-263. 
I to sprawia, że nazwyamy go osobą. Godność ludzka zobowiązuje do szacunku dla drugiego człowieka, natomiast prawa ludzkie są wskazówkami, na czym ten szacunek polega ${ }^{18}$.

\section{Niezbywalny charakter godności człowieka}

W świetle powyższego można przyjąć następującą definicję ludzkiej godności: Jest to wysoki status moralny posiadany przez każdą istotę ludzką. Godność człowieka jest wartością daną, nieodłączną od ludzkiej istoty i niezależną od jakiejkolwiek cechy, która może się zmieniać i posiadać różne stopnie. Podstawę tego statusu można znaleźć w takich uzdolnieniach, jak abstrakcyjne myślenie, język, sumienie i wolna wola, które istota ludzka może rozwijać i praktykować, o ile nie jest ograniczona przez chorobę, przymus lub nakaz. Posiadanie ludzkiej godności implikuje pewne niezmienne obowiązki wobec innych ludzi, do których należą: szacunek dla życia, wolności i bezpieczeństwa osób oraz odpowiedzialne zarządzanie światem zwierząt i całą naturą. Chrześcijaństwo dodaje do tego obowiązek czci dla Boga ${ }^{19}$.

W ocenie i odkrywaniu godności człowieka konieczne jest zatem uznanie jedności pomiędzy logosem i etosem. Metafizyczna koniunkcja logosu i etosu znajduje się w metaetycznym intuicjonizmie etyki personalistycznej. Jej teza brzmi: człowiek jako osoba ma taką godność, że z powodu niej samej należy mu się afirmacja. To z kolei zakłada znany $\mathrm{z}$ doświadczenia fakt, że osobowe „bycie innym i wyższym” człowieka oraz jego samoistna wartość mają swą podstawę i realnie istnieją w ontyczno-aksjologicznej strukturze osobowego bytu ludzkiego. Godność jest dana działającemu człowiekowi będącemu podmiotem poznania obiektywnie i bezpośrednio jako fakt, a zarazem bezwarunkowo zadana mu jako podmiotowi wolności.

Pojęcie godności jest terminem mającym swój odpowiednik w rzeczywistości ludzkiego bycia, niedającej się jednak zredukować do empirycznie uchwytnych cech. Dlatego normy etyczne, a także sama zasada godności ludzkiej są zdaniami w logicznym sensie, takimi które są prawdziwe lub fałszywe. Nie można ich przełożyć na zdania empiryczne. Te etyczne zdania dają się zweryfikować (i usprawiedliwić) za pomocą prawdziwej antropologii, której zadanie

${ }_{18}$ Por. Jan xxıII, Encyklika Pacem in terris o pokoju między wszystkimi narodami opartym na prawdzie, sprawiedliwości, miłości i wolności (11.04.1963), Kraków 2003, nr 80.

${ }_{19}$ Por. H. Seweryniak, Świadectwo i sens, Płock 2003, s. 77-88. 
polega na tym, by ukazać prawdziwe poznanie logosu, czyli prawdy o człowieku i o jego ontyczno-aksjologicznej strukturze osobowego bytu, a dzięki temu określić i wyjaśnić obiektywne normy autentycznej moralnej afirmacji godności ludzkiej. Tylko antropologia ukazująca prawdziwy obraz człowieka i pozwalająca kierować się prawdą o człowieku, przedkłada takie kryteria, które wyjaśniają godność ludzką i uzasadniają normy jej afirmacji. W ten sposób objawia się kulturotwórcza rola koniunkcji logosu i etosu, prawdy o człowieku i poszanowania jego godności.

Dla etyki niezwykle ważną sprawą jest rozróżnianie doxa i episteme, opinii (mniemania) i poznania, poglądu i wglądu (rozumienia). W ten sposób można uniknąć redukowania poznania prawdy o człowieku do jakiejś opinii o sobie samym, to znaczy uniknąć redukowania prawdziwej antropologii do antropodoksji. W odniesieniu do etycznej zasady personalizmu oznacza to zamianę afirmacji osoby ze względu na nią samą na afirmację osoby ze względu na jej opinię o sobie samej.

Przeciwnicy koniunkcji logosu i etosu pomijają całkowicie logos w definiowaniu godności człowieka, uznając że ta wartość nie ma żadnego znaczenia i nie wpływa w żaden sposób na człowieka. W związku z tym trzeba im zadać pytanie, czy potrafią oni zatem przedstawić prawdziwy obraz człowieka, który mógłby zapewnić ich etyce prawdziwy humanizm, a nie tylko jakiś jego pozór. Czy biorą na serio fakt transcendencji prawdy o człowieku w procesie poznania? Jeśli nie, to brak im jakiegokolwiek kryterium pozwalającego stwierdzić, $\mathrm{w}$ jakim stopniu samorozumienie człowieka jest poprawne, a opierająca się na nim afirmacja osoby w moralnym działaniu nie jest pozorna. Do oceny prawdy samopoznania brak im najwyższego kryterium, a tym samym obiektywnego kryterium akceptacji logosu (prawdy) i godności ludzkiej (etosu). Nasza teza o koniunkcji logosu i etosu godności ludzkiej potwierdza dodatkowo wagę tego rodzaju pytań.

Odpowiedź na nie w postaci naszej tezy o niezbywalności osoby ludzkiej jest rozstrzygająca w przezwyciężaniu kryzysu pojęcia osoby ludzkiej i w budowaniu „cywilizacji miłości” (Paweł vi), w której uznaje się całą strukturę logicznej i moralnej spuścizny: Homo homini homo. W dyskusjach prowadzonych w tradycyjnym nurcie katolickiej nauki społecznej zawsze powraca się do problemu godności osoby. Głoszenie potrzeby solidarnego urzeczywistniania dobra wspólnego przyjmuje ostatecznie za punkt odniesienia zawsze godność osoby ludzkiej. Według encykliki Piusa xi Quadragesimo anno: „wszelka czynność społeczna bowiem powinna w pojęciu i istocie swojej wspomagać członki ciała 
społecznego" ${ }^{20}$, tj. w ostatecznym wymiarze być pomocą świadczoną dla dobra indywidualnej osoby, gdyż jak czytamy w soborowej konstytucji Gaudium et spes to właśnie człowiek, osoba jest „twórcą, ośrodkiem i celem” ${ }^{21}$ nie tylko całej gospodarki, lecz również całości społecznych relacji. „Porządek zatem społeczny i jego rozwój winien być nastawiony nieustannie na dobro osób, ponieważ od ich porządku winien być uzależniony porządek rzeczy, a nie na odwrót" ${ }^{\prime 2}$.Zasada pomocniczości, jako ogólna i otwarta zasada organizacji dobra wspólnego, stanowi próbę takiego połączenia aspektu praw i wolności jednostki (odpowiedzialność indywidualna) z aspektem praw społecznych (świadczenie pomocy), aby każdy człowiek mógł prowadzić życie godne osoby ludzkiej.

Do godności i praw człowieka duże znaczenie przywiązuje Kościół katolicki. W dokumentach Soboru Watykańskiego II pojęcie „godność” pojawia się 88 razy. Według wspomnianej konstytucji Gaudium et spes godność osoby ludzkiej, jej niezwykłość i wrodzone dostojeństwo wynikają stąd, że człowiek przerasta wszystkie rzeczy, które są na ziemi ${ }^{23}$. Godność ta przynależy mu na stałe jako wrodzona, wynikająca z faktu „bycia człowiekiem”24. Sobór ostatecznie podbudowuje godność ludzką podobieństwem człowieka do Boga i jego nadprzyrodzonym powołaniem do zjednoczenia z Bogiem. Godność człowieka jest istotnym elementem soborowej antropologii. „Wszystko co powiedzieliśmy o godności osoby ludzkiej, o wspólnocie ludzi, o głębokim znaczeniu aktywności ludzkiej, stanowi fundament stosunku między Kościołem i światem, a także bazę wzajemnego dialogu"25.

Godność człowieka jest wartością, którą chronią prawa człowieka. Sobór ujmuje godność ludzką statycznie, jako spełnioną, wyrastającą z człowieczeństwa, nienaruszoną i niezbywalną. Godność ta ma jednak także charakter dynamiczny, domaga się doskonalenia, jawi się jako zadanie ${ }^{26}$. Wrodzone

${ }^{20}$ Pius XI, Encyklika Quadragesimo Anno o chrześcijańskim ustroju społecznym (15.05.1931),Warszawa 2002, nr 79.

${ }^{21}$ Sobór Watykański II, Konstytucja duszpasterska o Kościele w świecie współczesnym Gaudium et spes, w: Sobór Watykański II, Konstytucje, dekrety, deklaracje, tekst łacińsko-polski, Poznań 2008, nr 63.

${ }^{22}$ Sobór Watykański II, Konstytucja Gaudium et spes, 26.

${ }^{23}$ Por. Sobór Watykański II, Konstytucja Gaudium et spes, 21.

${ }^{24}$ W. Bołoz, Personalistyczne uzasadnienie norm moralnych $w$ dokumentach Soboru Watykańskiego II, Warszawa 1981, s. 62.

${ }^{25}$ Sobór Watykański II, Konstytucja Gaudium et spes, 40.

${ }^{26}$ Por. Pius XI, Encyklika Quadragesimo anno, 118. 
atrybuty człowieka, leżące u podstaw jego godności: świadomość, wolność i odpowiedzialność, mogą odznaczać się różnym stopniem rozwoju i można z nich różnie korzystać. Atrybuty te powinny być utrwalane i promowane. Natura intelektualna powinna być udoskonalona przez mądrość, wolność, poprzez uwalnianie się od namiętności. Człowiek powinien zatem rozwijać się harmonijnie i integralnie. Promocja osoby, czyli jej „utwierdzanie i kształtowanie" stanowi, według dokumentów soboru, kryterium godziwości działania. Człowiek postępuje źle, gdy tę godność narusza, dobrze - gdy ją respektuje i promuje.

Z bogatej refleksji filozoficznej typologia rozumienia godności prowadzi nas do zagadnień socjalnych ${ }^{27}$. Socjologia odczytuje godność człowieka pod kątem społecznej i zawodowej roli człowieka ${ }^{28}$. Wyznacza mu pewien status życia, pewną pozycję, uznanie jego miejsca w hierarchii społecznej lub zawodowej. Kiedy socjologia mówi o człowieku, że jest „godny”, to przypisuje mu znaczenie uznania na pozycji społecznej i zawodowej, pewną wartość, szacunek, powagę, danie komuś przywilejów i miejsca pośród społeczności ludzkiej ${ }^{29}$.

Człowiek stanowi rzeczywistość nie tylko wyjątkową, doniosłą, lecz także treściowo bardzo bogatą ${ }^{30}$. Dlatego ograniczając się tylko do najbardziej podstawowych kwestii związanych z człowiekiem, można patrzeć na niego albo z perspektywy zasadniczych jego funkcji w społeczeństwie, albo z perspektywy wielorakich skutków jego działalności. Skutki te mogą zaś być pozytywne albo negatywne. Nietrudno zauważyć, że to drugie ujęcie rzeczywistości człowieka, czyli patrzenie na niego przez pryzmat działania, a nie funkcji, stanowi ostatecznie pochodną tej zasadniczej ontologicznej perspektywy rozumienia człowieka, i dlatego to właśnie spojrzenie jest spojrzeniem podstawowym, warunkującym wszystko inne, co o człowieku da się powiedzieć.

Takie rozumienie człowieka szczególnie uwidacznia się w nauczaniu Jana Pawła II. Przez myśl Jana Pawła II rozumieć można system myślowy, stanowiący istotną część systemu filozoficznego, wypracowanego przez niego

${ }_{27}$ Por. Jan Paweł II, Encyklika Centesimus annus w setną rocznicę Rerum novarum (1.05.1991), Kraków 2013, nr 13.

${ }^{28}$ Por. Paweł vi, Encyklika Populorum progressio. o popieraniu rozwoju ludów (26.03.1967), w: Dokumenty nauki społecznej Kościoła, red. M. Radwan, L. Dyczewski, A. Stanowski, t. 1, Rzym-Lublin 1987, nr 15.

${ }^{29}$ Por. J. Majka, Filozofia społeczna, Wrocław 1982, s. 285-37o.

${ }^{30}$ Por. Jan XXIII, Encyklika Mater et magistra o współczesnych przemianach społecznych w świetle zasad nauki chrześcijańskiej (15.05.1961), Wrocław 1997, nr 2. 
w okresie bycia profesorem, kapłanem, biskupem i kardynałem, zanim został powołany na Stolicę Piotrową. Myśl ta zawarta jest zarówno w nauczaniu pasterskim, jak i w pismach o charakterze naukowym z tego okresu. Kiedy natomiast Karol Wojtyła podjął posługę papieską, rozpoczął drugi okres w prezentowaniu myśli o człowieku i człowieczeństwie. Pomiędzy tymi dwoma okresami istnieje mocne i organiczne powiązanie, choć należy zauważyć, iż dokumenty z okresu pontyfikatu Jana Pawła II charakteryzuje wyraźniejsze ubogacenie wizji człowieka. Ta bogata twórczość papieża opiera się na silnym fundamencie filozoficznym. By uchwycić tę bogatą twórczość, trzeba wrócić do pewnego źródła.

Chodzi o jedną z najbardziej rozbudowanych teorii człowieka, jaką prezentuje filozofia arystotelesowska. Można mówić tutaj o wielkiej teorii człowieka nadbudowanej na doświadczeniu przednaukowym. Arystoteles zastosował przy wyjaśnianiu jego struktury swoją teorię aktu i możności. Wychodząc z założenia, że akt i możność są sobie koniecznościowo, transcendentalnie przyporządkowane, uzyskał łatwo swoisty „wehikuł” rozumienia i sondowania wewnętrznej struktury bytu ludzkiego. W oparciu o ten model struktura bytowa człowieka zostaje wymodelowana zgodnie ze schematem substancji i przypadłości. Podmiot jest substancją złożoną z duszy i ciała. Substancja ta działa poprzez swoje „władze”, pojęte jako bezpośrednie źródła akcydentalnego działania. Charakter tego źródła ujawnia się w samym działaniu, zdeterminowanym przez swój przedmiot właściwy. Taki obraz człowieka jest całkowicie „zobiektywizowany”, czyli związany z obiektami, a więc przedmiotami warunkującymi działanie. One stanowią jedyny wziernik pozwalający na spojrzenie w głąb struktury bytowej człowieka ${ }^{31}$.

Według tego modelu substancja miałaby być stale tożsamym, niezmiennym podmiotem, a zmienne działanie byłoby tylko czymś akcydentalnym, w niczym nie naruszając substancjalnego rdzenia bytu ludzkiego. To na takiej koncepcji człowieka w dużej mierze opiera się sposób myślenia i argumentacji zaproponowany w średniowieczu przez św. Tomasza z Akwinu, choć i on nieco zmodyfikował teorię arystotelesowską. Tymczasem wiemy też, że człowiek urzeczywistnia się jako człowiek przez swoje czynności, zwłaszcza czynności duchowe, jak np. poznanie intelektualne, akty decyzyjne, twórczość. Dla wielu ludzi, jak pokazała historia myśli ludzkiej, sam człowiek w swych wewnętrznych przeżyciach stawał się sobie najbliższym

${ }^{31}$ Por. G. Haeffner, Wprowadzenie do antropologii filozoficznej, Kraków 20o6, s. 182-183. 
przedmiotem analiz, jako świadek tego wszystkiego, co się w nim dzieje. Człowiek w swych duchowych przeżyciach jest jakby modelem rozumienia Boga i świata. Dlatego właśnie św. Augustyn stwierdzi: „Chcę poznać Boga i duszę. [Rozum] Czy nic więcej? [A.] Nic zgoła"32. Augustyńska metoda analizy duchowych przeżyć człowieka, w których stale występuje samowiedza, zwana niekiedy przez niego memoria lub mens, jako podstawa dwu dalszych strumieni życia duchowego - poznania i miłości, stała się w dużej mierze wzorcem filozofowania dla tych, których bardziej interesowały w filozofii sprawy człowieka, aniżeli ogólna teoria bytu. W kulturze chrześcijańskiej za metodą św. Augustyna poszli ci, których szczególnie interesowało życie wewnętrzne człowieka, zwłaszcza jego wewnętrzny stosunek do Boga. Stąd mistycy średniowiecza i renesansu bardziej tkwią w kręgu myśli św. Augustyna niż Arystotelesa i ścisłych scholastyków ${ }^{33}$.

\section{Bibliografia}

Balthasar H. U. von, Teodramatyka. Druga osoba dramatu, Kraków 2003. Gesché A., Człowiek, Poznań 2005.

Głódź M., Zagadka substancji wszechrzeczy i człowieka, w: M. Heller, J. Życiński, Wszechświat - maszyna czy myśl?, Kraków 1998, s. 127-142.

Gnilka J., Teologia Nowego Testamentu, Kraków 2002.

Haeffner G., Wprowadzenie do antropologii filozoficznej, Kraków 2006.

Heschel A. I., Człowiek nie jest sam, Kraków 2001.

Jan XxIII, Encyklika Mater et magistra o współczesnych przemianach społecznych w świetle zasad nauki chrześcijańskiej (15.05.1961), Wrocław 1997.

Jan XXIII, Encyklika Pacem in terris o pokoju między wszystkimi narodami opartym na prawdzie, sprawiedliwości, miłości i wolności (11.04.1963), Kraków 2003. Jan Paweł II, Encyklika Centesimus annus w setną rocznicę Rerum novarum (1.05.1991), Kraków 2013.

Jurgen H., Faktizität und Geltung. Beiträge zur Diskurstheorie des Rechts und des demokratischen Rechtsstaats, Frankfurt 1992.

Kotowicz R., Etyka życia, Kraków 1998.

${ }^{32}$ Augustyn, Solilokwia II, 7, przeł. A. Świderkówna, w: Dialogi filozoficzne, Warszawa 1953, t. 2, s. 13 .

${ }_{33}$ Por. G. Haeffner, Wprowadzenie do antropologii filozoficznej, s. 96-99. 
Krąpiec M. A., Człowiek, w: Powszechna encyklopedia filozofii, t. 2, Lublin 2001, s. $376-386$.

Krąpiec M. A., Kryzys społeczno-gospodarczy kryzysem człowieka, w: O życie godne człowieka - w nurcie zagadnień posoborowych, t. 19, Warszawa 1990, s. 251-263. Legutko R., Podzwonne dla błazna, Kraków 2006.

Majka J., Filozofia społeczna, Wrocław 1982.

Mazurek F. J., Godność osoby ludzkiej podstawa praw człowieka, Lublin 2001.

Paweł vi, Encyklika Populorum progressio. o popieraniu rozwoju ludów (26.03.1967), w: Dokumenty nauki społecznej Kościoła, red. M. Radwan, L. Dyczewski, A. Stanowski, t. 1, Rzym-Lublin 1987, s. 391-416.

Pius XI, Encyklika Quadragesimo Anno o chrześcijańskim ustroju społecznym (15.05.1931), Warszawa 2002.

Połoz W., Personalistyczne uzasadnienie norm moralnych $w$ dokumentach Soboru Watykańskiego II, Warszawa 1981.

Seweryniak H., Świadectwo i sens, Płock 2003.

Singer P., Practical Ethics, Cambridge 1979.

Sobór Watykański II, Konstytucja duszpasterska o Kościele w świecie współczesnym Gaudium et spes (7.12.1965), w: Sobór Watykański II, Konstytucje, dekrety, deklaracje, tekst łacińsko-polski, Poznań 2008, s. 824-981.

\section{Streszczenie}

Ideą przewodnią w całej nauce społecznej Kościoła jest wciąż powracająca prawda o godności osoby ludzkiej. Warto przeanalizować to zagadnienie, gdyż nieodłącznie towarzyszy ono społecznemu nauczaniu Kościoła. O godności człowieka świadczy jego natura. W ludzkiej naturze skupia się element świata materialnego i duchowego. Człowiek przerasta świat materialny - uznając w sobie element duchowy, nie daje się zredukować jedynie do rzeczywistości sprowadzonej do fizycznych czy społecznych uwarunkowań. Szczególną godnością odznacza się ludzki rozum. Uczestniczy on bowiem w świetle myśli Bożej, dzięki czemu człowiek przerasta świat rzeczy. Niniejsze opracowanie ukazuje inny - nadprzyrodzony wymiar godności człowieka. O godności tej świadczy Objawienie, zwłaszcza Pismo Święte wskazujące na fakt stworzenia człowieka przez Boga. Człowiek w tym ujęciu jest obrazem Boga. Z uwagi na nadprzyrodzony aspekt ludzkiej godności możemy mówić o tym, że człowiek został wyniesiony do godności synostwa Bożego. To właśnie człowiek jest celem Bożego objawienia, do człowieka przemawiał Chrystus, dla niego cierpiał, został 
skazany na śmierć i zmartwychwstał. Aspekt nadprzyrodzony ludzkiej godności wyraża się również w misji Kościoła Chrystusowego, dla którego właśnie człowiek jest ,jedyną drogą".

\section{Słowa kluczowe}

godność człowieka, katolicka nauka społeczna, nadprzyrodzony wymiar człowieka, etyczny wymiar człowieka, socjalny wymiar człowieka

\section{Summary}

\section{Supernatural Dimension of Human Dignity}

A leading idea in the Churchentire social teaching is a continuously returning truth about dignity of a human person. It is worth to analyse this issue, as it is an inseparable companion of the social teaching of the Church. This work presents the supernatural dimension of human dignity. The dignity is supported by the Revelation, especially the Holy Bible indicating the fact that human was created by the God. In this approach, human is the God's image. Due to the supernatural aspect of human dignity we can say that human being given a dignity of the God's son and daughter became brother and sister of Christ. This is a man, who is the purpose of God's revelations, it is a man, to whom Christ was talking, He suffered for him, was sentenced to death and resurrected. The supernatural aspect of human dignity is also expressed in the mission of the Church of Christ, to which it is a man, who is "the only path."

\section{Keywords}

human dignity, Catholic social teaching, the supernatural dimension of man, the ethical dimension of man, social dimension of man 